Article

\title{
The Study on Extraction Process and Analysis of Components in Essential Oils of Black Pepper (Piper nigrum L.) Seeds Harvested in Gia Lai Province, Vietnam
}

\author{
Thien Hien Tran ${ }^{1,2}$, Le Ke Ha ${ }^{1}$, Duy Chinh Nguyen ${ }^{1}{ }^{1}$, Tan Phat Dao ${ }^{1}$, Le Thi Hong Nhan ${ }^{3}$,

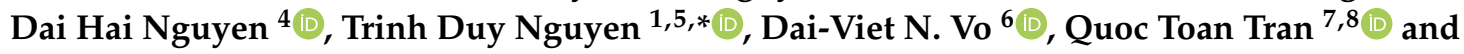 \\ Long Giang Bach ${ }^{1,2}$ \\ 1 NTT Hi-Tech Institute, Nguyen Tat Thanh University, Ho Chi Minh City 700000, Vietnam; \\ hientran.cg@gmail.com (T.H.T.); lekeha1995@gmail.com (L.K.H.); ndchinh@ntt.edu.vn (D.C.N.); \\ daophat147@gmail.com (T.P.D.); blgiang@ntt.edu.vn (L.G.B.) \\ 2 Faculty of Chemical Engineering and Food Technology, Nguyen Tat Thanh University, \\ Ho Chi Minh City 700000, Vietnam \\ 3 Department of Chemical Engineering, HCMC University of Technology, VNU-HCM, \\ Ho Chi Minh City 700000, Vietnam; lthnhan@hcmut.edu.vn \\ 4 Institute of Applied Materials Science, Vietnam Academy of Science and Technology, \\ Ho Chi Minh City 700000, Vietnam; nguyendaihai0511@gmail.com \\ 5 Department of Chemical Engineering, Pukyong National University, Busan 608-737, South Korea \\ 6 Faculty of Chemical and Natural Resources Engineering, Universiti Malaysia Pahang, Lebuhraya Tun Razak, \\ Gambang 26300, Malaysia; vietvo@ump.edu.my \\ 7 Institute of Natural Products Chemistry, Vietnam Academy of Science and Technology, Hanoi 122100, \\ Vietnam; tranquoctoan2010@gmail.com \\ 8 Graduate University of Science and Technology, Vietnam Academy of Science and Technology, \\ Hanoi 122100, Vietnam \\ * Correspondence: ndtrinh@ntt.edu.vn; Tel.: +84-287-108-0889
}

Received: 17 December 2018; Accepted: 21 January 2019; Published: 22 January 2019 updates

\begin{abstract}
Black pepper (Piper nigrum L.) is a tropical crop with extensive medicinal potential in ethnomedicine and nutraceutical applications. The essential oil of black pepper finds wide applications in inhabitation of respiratory infections and soothing of muscular pains due to its warming and energizing property. The pungent bioactive piperine is responsible for this function, and therefore, efficient technology is required for an optimal extraction process of this compound. In the present article, we have developed a procedure for extracting black pepper essential oil from Vietnam, optimizing conditions that affect the extraction process. The effect of process parameters, namely material size, preservation method, the concentration of sodium chloride, the concentration of soak time, the ratio of material to water, temperature extraction, time extraction on the extraction yield, and relative efficiency were investigated. Results demonstrated that $20 \mathrm{~g}$ of black pepper milled with a mesh size of 160 obtained $0.48 \mathrm{~g}$ of essential oil (2.4\%) at a raw material to water ratio of $1 / 21$ $(\mathrm{g} / \mathrm{mL})$ at $150^{\circ} \mathrm{C}$ in a time of $5.2 \mathrm{~h}$. GC-MS (Gas chromatography-mass spectrometry) spectra showed that 3-carene (29.21\%), D-limonene (20.94\%), caryophyllene (15.05\%), and $\beta$-pinene $(9.77 \%)$ were present as major components. These results suggested that the essential oil extracted from Vietnamese black pepper is applicable in the manufacturing processes of insecticides and air deodorizers.
\end{abstract}

Keywords: black pepper (Piper nigrum L.), essential oils; hydrodistillation; chemical composition analysis; GC-MS 


\section{Introduction}

Herbs and spices have been extensively used in traditional medicine and are considered an important part of human diets as a colorant, flavorant, and aroma enhancer. Essential oils (EOs) obtained from the aromatic plants have a wide variety of biological properties and have been used as products for pharmaceuticals, agronomics, food, sanitary products, cosmetics, and perfume and in cosmetics industries [1-8].

Black pepper (Piper nigrum L.), belonging to the Piperaceae family, is a significant agricultural crop with high commercial, economic, nutritional, health, and medicinal benefits [9-12]. The plant is a climbing perennial plant which is native to South East Asia and China. However, its cultivation is widespread in tropical regions ranging from many parts of India, Brazil, Indonesia, Sri Lanka, Vietnam, to Malaysia. Black pepper is commonly used as a spice for flavoring foods in oriental countries. Production of commercial peppers is dominated by Vietnam, whose black pepper export accounts for about $34 \%$ of the world's production, and 95\% of Vietnam's exported pepper is consumed in the US, India, Netherlands, and Germany.

Apart from nutrition and aroma, black pepper also exhibits multiple valuable health characteristics, including antioxidant, antimicrobial, anticancer, anti-inflammatory, and gastroprotective effects, aiding in the prevention of chronic ailments and providing physiological benefits [13-17]. Such benefits have been explored and utilized in folk medicine extensively. Among the components, piperine, existing mostly in the essential oil of the black pepper, is responsible for the pungency properties. Piperine is a bioactive constituent and plays an important role in soothing muscular aches and pains, relieving digestion issues, and healing respiratory infections [18-21]. For flavor and aroma, responsible components include $\alpha$ - and $\beta$-pinene, limonene, myrcene, linalool, $\alpha$-phellandrene, sabinene, $\beta$-caryophyllene, and germacrene-D. The essential oil of black pepper also finds use in the food and beverage industries and in cosmetics.

Due to the diverse use of the oil and the abundance of useful components, the extraction procedure of black pepper oil has a growing interest in the literature. Specifically, investigation on operation conditions for different extraction methods to optimize the oil yields has been extensively studied [22-27]. To extract the oil from black pepper, several techniques are employed including hydro-distillation, steam distillation, solvent extraction, supercritical $\mathrm{CO}_{2}$ extraction, and microwave extraction, where each of them could result in varying compositions and yields. Among such methods, hydrodistillation is common and feasible in larger scale production due to economic reasons. Hydrodistillation could be performed either by heating the mixture consisting of material and water or by passing steam through the sample materials [28-31].

The purpose of the present experiment was to determine the optimal conditions of the hydrodistillation procedure and chemical composition of essential oils obtained from seeds of black pepper (Piper nigrum L.) fruits grown in Vietnam. The effects of the hydrodistillation extraction parameters (material size, preservation method, the concentration of sodium chloride, the concentration of soak time, ratio material to water, temperature extraction, time extraction) on the extraction rate were examined in a series of experiments conducted in a laboratory scale apparatus. The extraction product was then analyzed and its chemical constituents were identified and quantified using GC-MS (Gas chromatography-mass spectrometry).

\section{Materials and Methods}

\subsection{Materials}

The materials used during the study were black pepper (Piper nigrum L.) seeds, which were grown, harvested and processed in Chu Se District, Gia Lai Province (13 $49^{\prime} 21^{\prime \prime}$ N $108^{\circ} 2^{\prime} 37^{\prime \prime}$ E). First, black pepper seeds were picked, dried, screened, and then proceeded to grinding using grinder (Sunhouse SHD 5323, Hanoi, Vietnam). To reduce the loss of essential oil during the milling process, the pepper was cooled (at $10^{\circ} \mathrm{C}$ ) in a refrigerator (Alaska, LC-743H, Ho Chi Minh City, Vietnam) 
for $2 \mathrm{~h}$ before milling. Then, the ground pepper particles were filtered with a wire mesh (with sizes ranging from 20 to 160 mesh). Seeds that did not pass through the screen were cooled and milled again. The purpose of pre-cooling is to reduce the undesirable odor and volatility of the materials after milling, which is caused at elevated temperatures. Finally, sodium chloride ( $\mathrm{NaCl}$, Bach Khoa Ltd., Ho Chi Minh City, Vietnam) was dissolved in water and added to the flask containing the material, followed by gentle shaking of the brine/material suspension.

\subsection{Extraction of Essential Oil}

After being soaked with $\mathrm{NaCl}$ solution for the required time period, $20 \mathrm{~g}$ of black pepper was placed into a $1000 \mathrm{~mL}$ volume flask connected directly to the Clevenger apparatus (Bach Khoa Ltd., Ho Chi Minh City, Vietnam) and heated with the Heating Mantle User Manual heater (1000.EU.05, 300 W, Glassco Laboratory Equipment Pvt. Ltd., Ambala Cantt, India). The experimental set up for the extraction stage is illustrated in Figure 1. The extraction time is started when the first drop of condensed essential oil is condensed and dropped into the oil extraction system. After the extraction process is completed, the essential oil is recovered and dehydrated with sodium sulfate $\left(\mathrm{Na}_{2} \mathrm{SO}_{4}\right.$, Sigma-Aldrich, St. Louis, MO, USA) and stored in a storage tank at $10^{\circ} \mathrm{C}$.

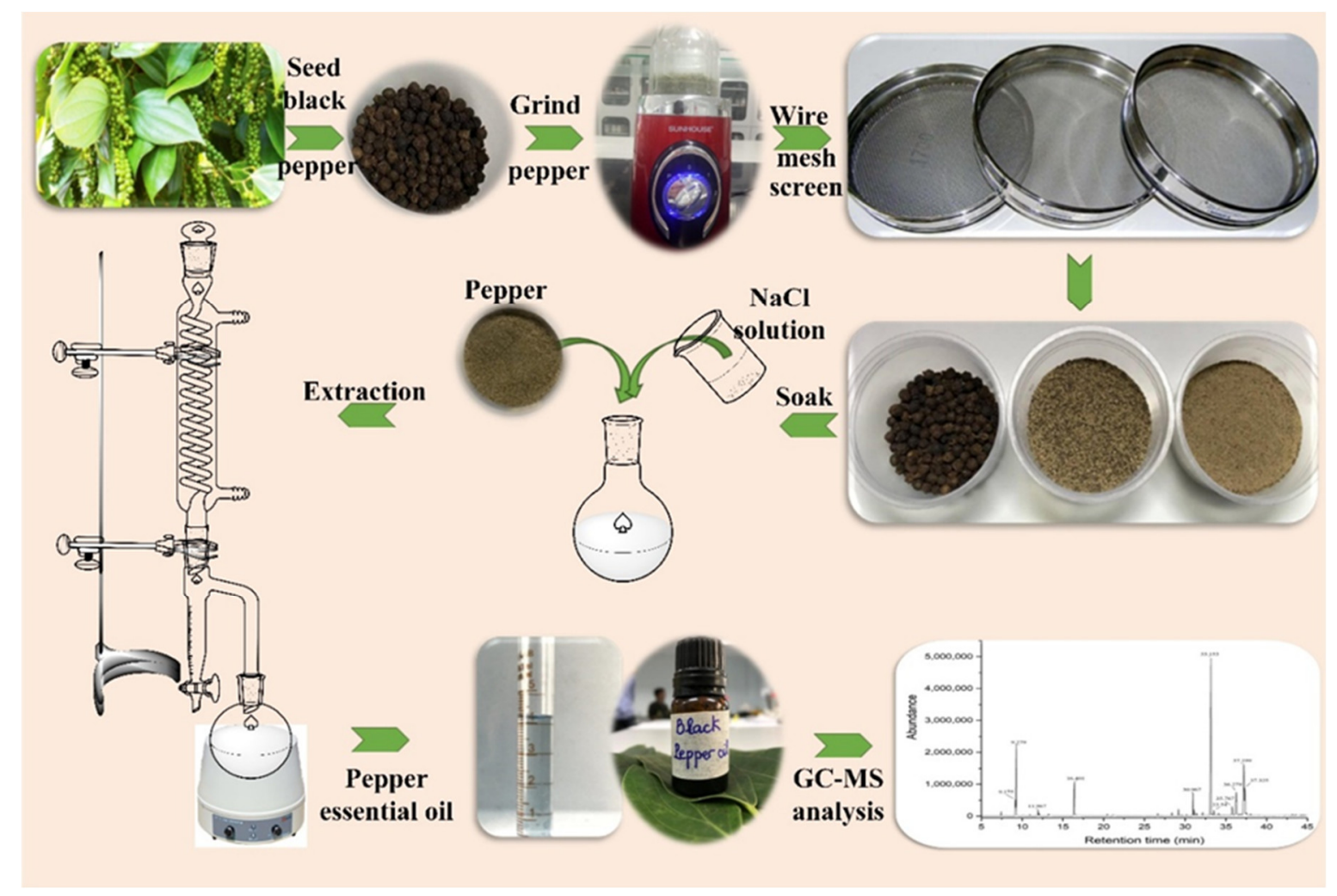

Figure 1. The process of black pepper essential oil extraction by hydro-distillation.

The yield of black pepper oil obtained (\%) is calculated by the following formula:

$$
\text { Yield of black pepper oil }(\%)=\frac{\text { the amount of essential oil obtained }(\mathrm{g})}{\text { the amount of black pepper originally used }(\mathrm{g})}
$$

\subsection{Optimizing the Extraction of Essential Oils by Hydrodistillation}

Factors affecting the extraction of black pepper essential oil, including material size, preservation conditions, concentration and soak time in the $\mathrm{NaCl}$ solution, and distillation conditions, were examined in this study. First of all, considered sizes of the material included whole seeds, 
mesh 40, and mesh 160, where the latter two correspond to 40 and 160 mesh size filtration after grinding. Following that, the influence of raw material preservation was also investigated by taking into account different conditions including the temperature (room temperature and cold storage of $10{ }^{\circ} \mathrm{C}$ ), state of the lid (closed lid and open lid-Figure 2), and time of preservation (24-72 h). In addition, the concentration and soak time of the $\mathrm{NaCl}$ solution were investigated, ranging from $1-5 \%$ and from $1-5 \mathrm{~h}$, respectively. Finally, the main conditions affecting the extraction process including the ratio of raw material to solvent $(1 / 5-1 / 35 \mathrm{~g} / \mathrm{mL})$, extraction time $(1-6 \mathrm{~h})$, and extraction temperature $\left(130-200{ }^{\circ} \mathrm{C}\right)$ were also surveyed. These experimental conditions were optimized through single-factor and the response surface methodology (RSM).

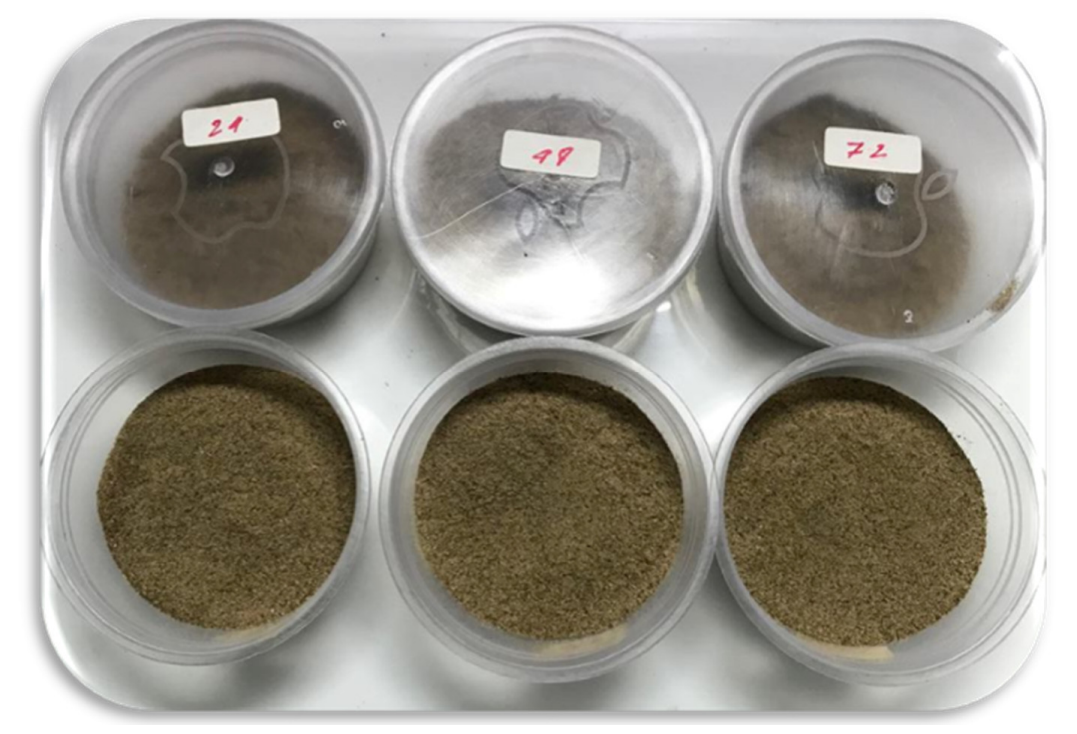

Figure 2. The storage conditions of the materials including lidded and open storage.

\subsection{Determination of Constituents of the Essential Oil by GC-MS}

Gas Chromatography-Mass Spectrometry (GC-MS, GC Agilent 6890 N, MS 5973 inert, Agilent Technologies, Santa Clara, CA, USA) was used to analyze the components contained in the essential oils of black pepper. Firstly, a $25 \mu \mathrm{L}$ sample of essential oil was added in $1.0 \mathrm{~mL}$ n-hexane (Sigma -Aldrich, St. Louis, MO, USA) and then dehydrated with $\mathrm{Na}_{2} \mathrm{SO}_{4}$. For the HP5-MS column, head column pressure was 9.3 psi. GC-MS were obtained under the following conditions: Carrier gas He; flow rate $1.0 \mathrm{~mL} / \mathrm{min}$; split 1:100; injection volume $1.0 \mu \mathrm{L}$; injection temperature $250{ }^{\circ} \mathrm{C}$; oven temperature progress included an initial hold at $50{ }^{\circ} \mathrm{C}$ for $2 \mathrm{~min}$, a rise to $80^{\circ} \mathrm{C}$ at $2{ }^{\circ} \mathrm{C} / \mathrm{min}$, a rise to $150{ }^{\circ} \mathrm{C}$ at $5^{\circ} \mathrm{C} / \mathrm{min}$, a rise to $200{ }^{\circ} \mathrm{C}$ at $10{ }^{\circ} \mathrm{C} / \mathrm{min}$ and a rise to $300^{\circ} \mathrm{C}$ at $20^{\circ} \mathrm{C} / \mathrm{min}$ for $5 \mathrm{~min}$.

\section{Results and Discussion}

\subsection{The Influence of Material Size on the Yield Essential Oil}

As the outer peels of the black pepper were thick and hard, the efficiency of the extraction process could be hindered without the peeling process. Therefore, it is necessary to perform treatment accordingly to the different sizes. Based on Figure 3, the amount of attained oil increased as the size of the black pepper decreased. The lowest yield at $0.25 \%$ is achieved without peeling, and significantly higher yields, at $1.6 \%$ and $1.8 \%$, were obtained at mesh 40 and mesh 160 , respectively. This is explained by the fact that when the black pepper is crushed, the cells containing oil were broken, facilitating the water penetration into the oil-containing bags. This, in turn, induces steam to transport the oil to the Clevenger apparatus. In addition, the powdered material for the attained oil has a natural odor and is light green compared to the material in seed size that has a light yellow color due to prolonged exposure to heat. 


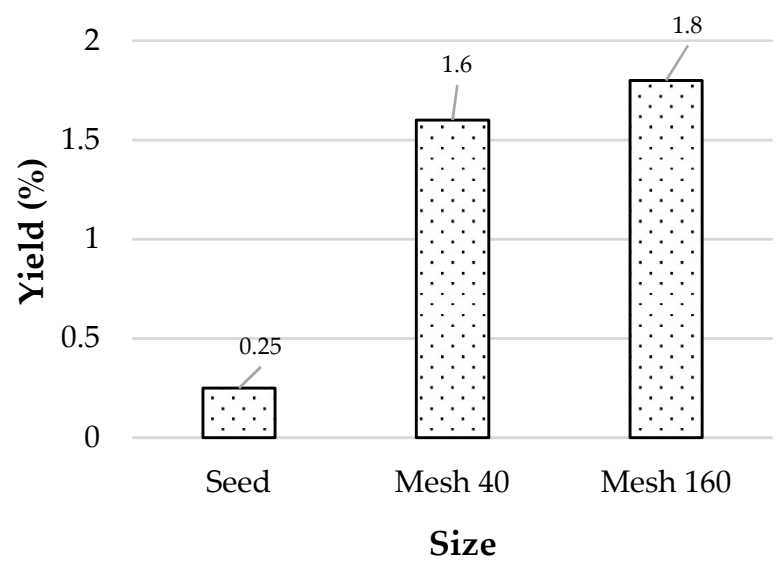

Figure 3. The influence of material size on the yield of essential oil.

\subsection{The Influence of the Preservation Method on the Yield of Essential Oil}

Figure 4 displayed the effect of the preservation method on the yield of black pepper extraction. Overall, lidded preservation gave higher oil content than the method of open storage. Cool preservation was also showed to be more efficient than storage at ambient temperature for maintaining the oil quantity. In terms of preservation period, longer storage time is also associated with lower oil content. Since essential oil is a mixture of numerous volatile compounds, the closed preservation and low temperature helped reduce the diffusion of essential oil into the air. Therefore, the best preservation conditions are selected at $10{ }^{\circ} \mathrm{C}$ with lidded preservation.

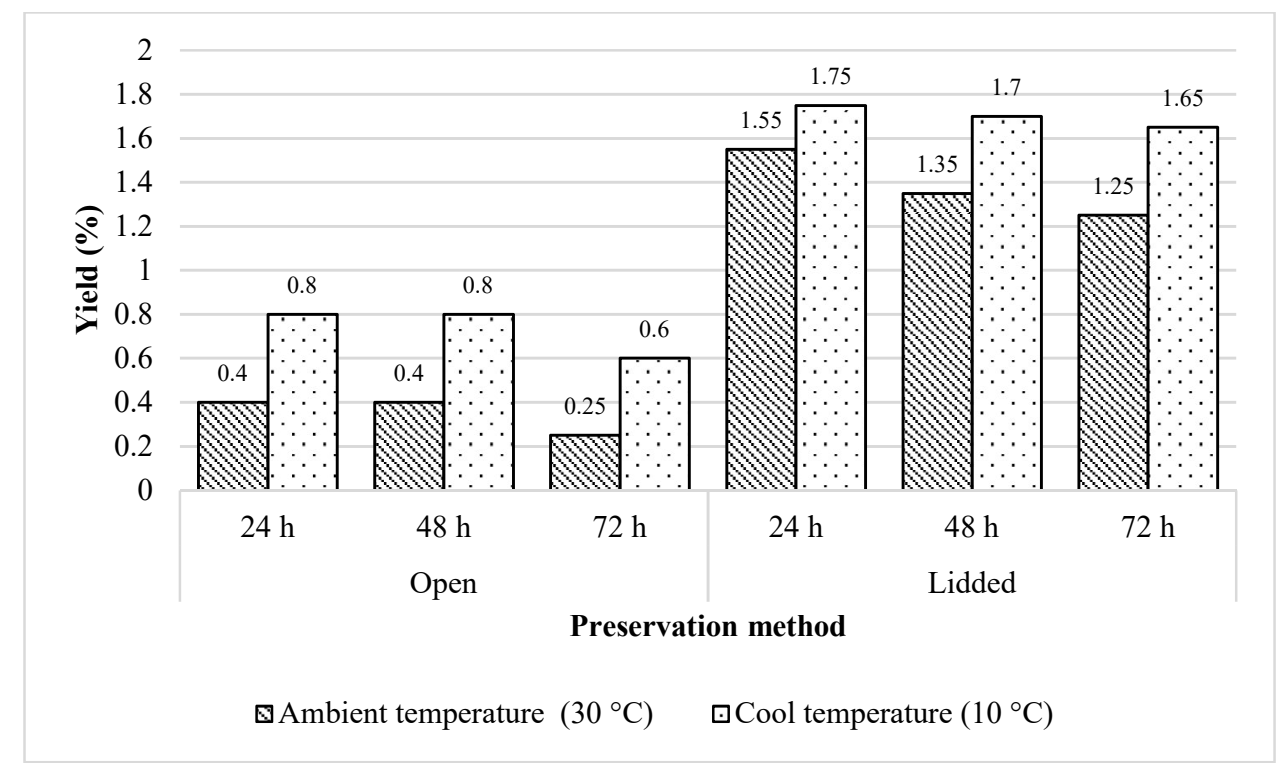

Figure 4. The influence of the preservation method on the yield of essential oil.

\subsection{The Influence of the Concentration of Sodium Chloride Solution on the Yield of Essential Oil}

The results from the investigation on the concentration of $\mathrm{NaCl}$ solution, used to immerse the raw material, were analyzed in Figure 5. In the extraction process, the mixture of essential oils, and water formed the emulsion. When adding salt to the extraction mixture, not only could the loss of essential oil in the form of emulsion be avoided, but the solubility of some non-polar components of essential oil into the water medium could also be reduced. In addition, the $\mathrm{NaCl}$ salt also plays an important role as an electrolyte that increases the density and polarization of water, which makes the separation of essential oil from water easier. As $\mathrm{NaCl}$ concentration reaches $2 \%$, oil yield was found to be declining. 
This could be explained by the osmotic pressure difference exerted by the higher solute concentration in the external environment in comparison with that inside the oil-containing cells. This effectively causes water inside the cell to osmose out, hindering the separation of essential oils from the material. Figure 5 showed that in the same extraction conditions, the sample with a $\mathrm{NaCl}$ concentration of $2 \%$ gave the best results with the yield of $2 \%$, and at a concentration of $4-5 \%$ the lowest results were observed at approximately $1.85 \%$. Therefore, the optimal concentration of $\mathrm{NaCl}$ is selected as $2 \%$ for the best yield of the essential oil.

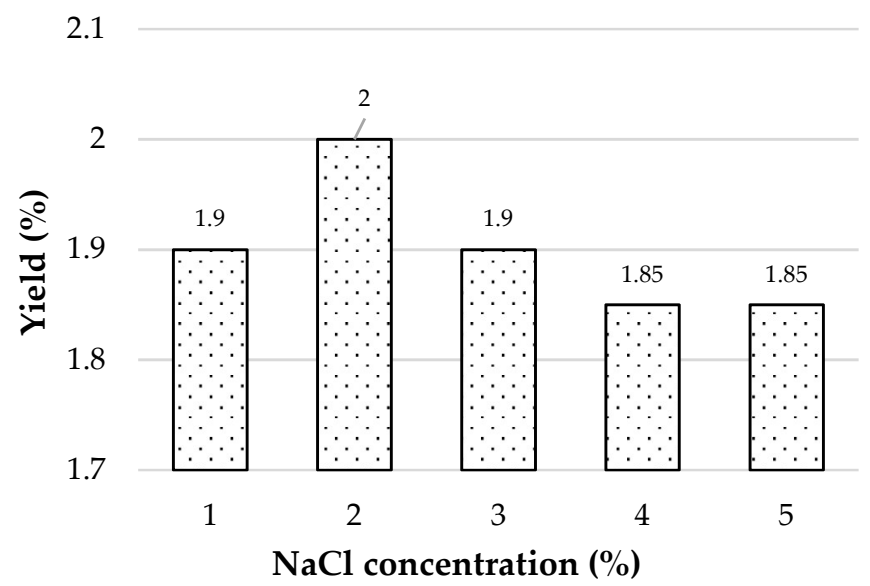

Figure 5. The influence of the concentration of sodium chloride solution on the yield of essential oil.

\subsection{The Influence of the Concentration of Soak Time on the Yield of Essential Oil}

From Figure 6, the soak time of the $\mathrm{NaCl} 2 \%$ solution prior to extraction evidently enhances the extract efficiency due to the time needed to induce the penetration of essential oil into the environment. On the other hands, prolonged exposure to salt also assists in breaking down oil bags, and high water emulsion could facilitate the transport of oil by steam. The results showed that oil yield was increasing with the soak period, reaching the maximum yield at $3 \mathrm{~h}$. Afterward, increasing soak time reduces extraction efficiency. Here, a 3-h soak time was selected for the highest efficiency of $2.2 \%$.

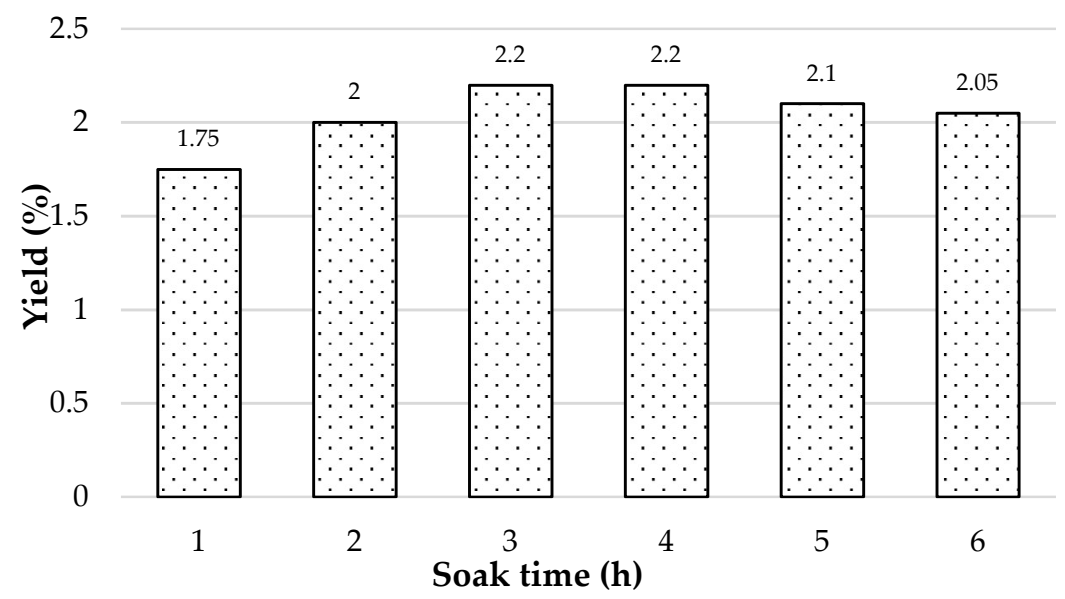

Figure 6. The influence of the concentration of soak time on the yield of essential oil.

\subsection{The Effect of the Material-to-Water Ratio on the Essential Oil Yield}

In the steam extraction process, when heating the mixture of water and material, the water vapor permeates the epidermis, which contains essential oils, breaks down the essential oils, and attracts the oil by steam. If the amount of water is insufficient to dissolve the colloids and salt wrapping the pouch of the essential oil, the oil is unable to escape. Using more water for extraction will cause 
greater diffusion of oil into the water, leading to enhanced solubility and increased the yield of soluble components, as shown in Figure 7. On the contrary, excess water could dissolve or emulsify the oil, reducing the amount of oil yield and the economic efficiency of the distillation due to increased energy consumption and extraction duration. Based on Figure 7, although both ratios of $1 / 20(\mathrm{~g} / \mathrm{mL})$ and $1 / 25(\mathrm{~g} / \mathrm{mL})$ gave the highest yield oil $(2.2 \%)$, the $1 / 20(\mathrm{~g} / \mathrm{mL})$ ratio could save a significant water use and in turn brings high economic value with only a marginal tradeoff in yield. Therefore, the ratio of $1 / 20(\mathrm{~g} / \mathrm{mL})$ was chosen for the next survey.

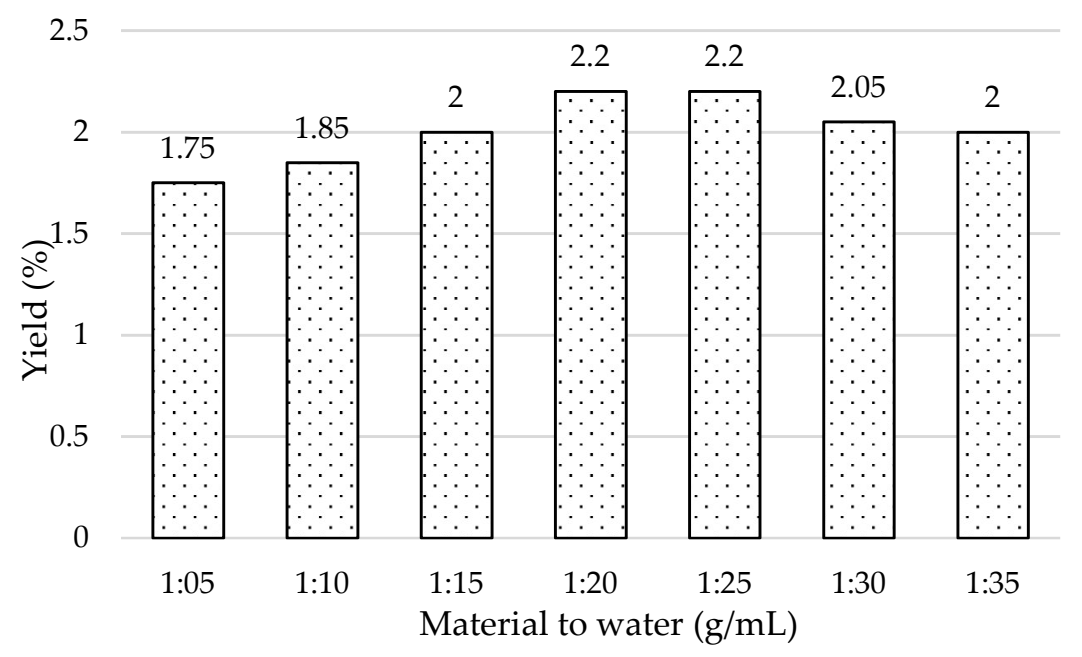

Figure 7. The influence of the material to water ratio on the yield of essential oil.

\subsection{The Influence of Temperature and Time Extraction on the Yield of Essential Oil}

In Figures 8 and 9, it is shown that as the temperature or time of the extraction increases, the yield of black pepper essential oil also increased. However, to an optimum threshold, the yield of essential oil was no longer increased, as shown in Figure 8. Based on Figure 8, the highest yield of oils was obtained at $180{ }^{\circ} \mathrm{C}$ at $2.25 \%$ and decreased to $1.95 \%$ at $200{ }^{\circ} \mathrm{C}$ due to the decomposition of some components at high temperature. At both temperatures, the essential oil is light yellow due to a small amount of material being splashed into the flask and burned. The temperature of $150^{\circ} \mathrm{C}$ is preferred to $180^{\circ} \mathrm{C}$ due to the energy efficiency and the green color of the oil, indicating the absence of denaturation of some substances in the product. On the other hand, Figure 9 showed that the extraction yield was found to cease rising when prolonging time extraction past $5 \mathrm{~h}$. Therefore, $5 \mathrm{~h}$ was chosen as the extraction time for subsequent surveys.

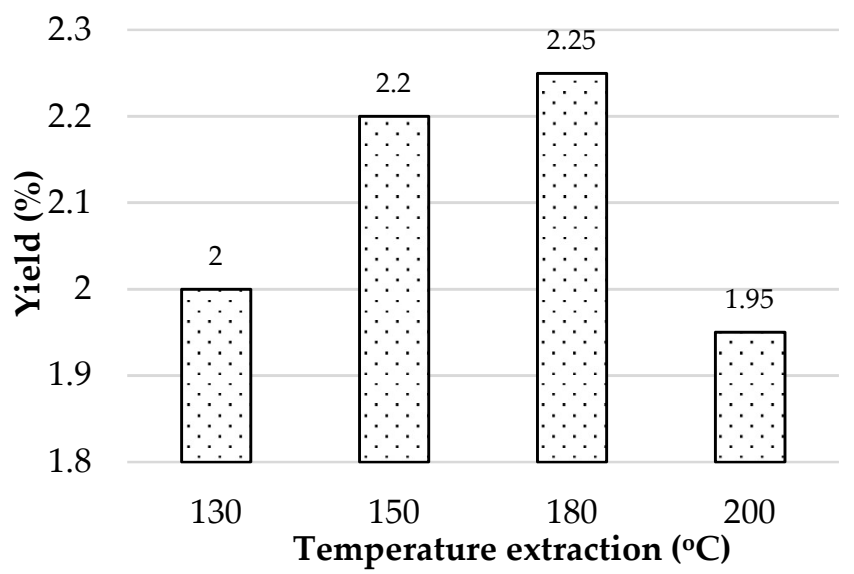

Figure 8. The influence of temperature extraction on the yield of essential oil. 


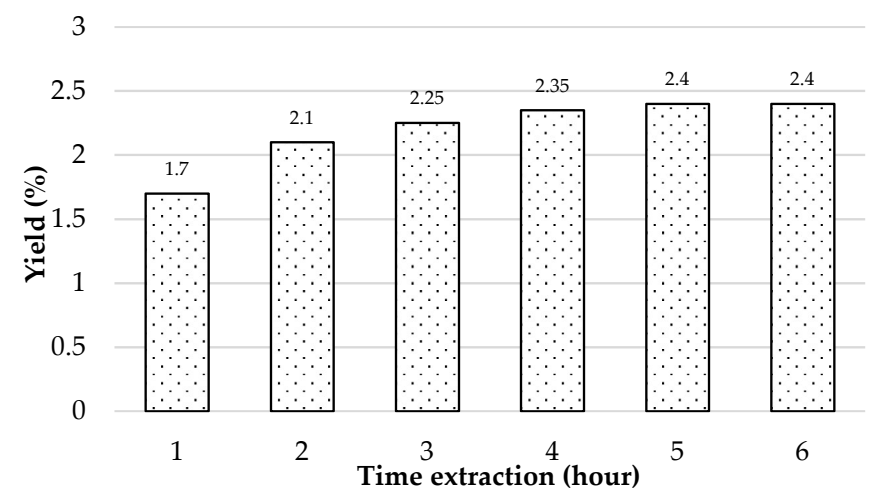

Figure 9. The influence of time extraction on the yield of essential oil.

\subsection{Optimization of the Experimental Conditions Using Response Surface Methodology (RSM)}

After having obtained the conditions for extraction of the oil, three factors, including a ratio of water-to-material of 20:1, extraction time of $5 \mathrm{~h}$, and an extraction temperature of $150{ }^{\circ} \mathrm{C}$ were selected for further optimization using RSM. The optimum conditions of the three variables, determined by aforementioned single factor investigations, were used to construct the experimental design for RSM. Accordingly, twenty experimental attempts were specified and performed. The Tables 1 and 2 below show the results of the twenty experiments and ANOVA (analysis of variance) results for the estimated quadratic model.

Table 1. Details of experimental attempts employed in the response surface methodology (RSM) optimization.

\begin{tabular}{|c|c|c|c|c|c|c|c|c|c|c|c|}
\hline \multirow[b]{2}{*}{ No. } & \multicolumn{3}{|c|}{ Parameters } & \multicolumn{2}{|c|}{ Yields } & \multirow[b]{2}{*}{ No. } & \multicolumn{3}{|c|}{ Parameters } & \multicolumn{2}{|c|}{ Yields } \\
\hline & $\begin{array}{c}\text { Ratio } \\
\text { (A) }\end{array}$ & $\begin{array}{c}\text { Time } \\
\text { (B) }\end{array}$ & $\begin{array}{c}\text { Temp. } \\
\left({ }^{\circ} \mathrm{C}\right)\end{array}$ & Actual & Predicted & & $\begin{array}{c}\text { Ratio } \\
\text { (A) }\end{array}$ & $\begin{array}{c}\text { Time } \\
\text { (B) }\end{array}$ & $\begin{array}{c}\text { Temp. } \\
\left({ }^{\circ} \mathrm{C}\right)\end{array}$ & Actual & Predicted \\
\hline 1 & 15 & 4 & 140 & 2.10 & 2.13 & 11 & 20 & 3.32 & 150 & 2.15 & 2.14 \\
\hline 2 & 25 & 4 & 140 & 2.20 & 2.19 & 12 & 20 & 6.68 & 150 & 2.25 & 2.25 \\
\hline 3 & 15 & 6 & 140 & 2.15 & 2.14 & 13 & 20 & 5 & 135 & 2.15 & 2.14 \\
\hline 4 & 25 & 6 & 140 & 2.15 & 2.17 & 14 & 20 & 5 & 167 & 2.20 & 2.20 \\
\hline 5 & 15 & 4 & 160 & 2.10 & 2.08 & 15 & 20 & 5 & 150 & 2.40 & 2.42 \\
\hline 6 & 25 & 4 & 160 & 2.15 & 2.17 & 16 & 20 & 5 & 150 & 2.40 & 2.42 \\
\hline 7 & 15 & 6 & 160 & 2.20 & 2.22 & 17 & 20 & 5 & 150 & 2.45 & 2.42 \\
\hline 8 & 25 & 6 & 160 & 2.30 & 2.28 & 18 & 20 & 5 & 150 & 2.45 & 2.42 \\
\hline 9 & 11.6 & 5 & 150 & 2.15 & 2.14 & 19 & 20 & 5 & 150 & 2.40 & 2.42 \\
\hline 10 & 28.41 & 5 & 150 & 2.25 & 2.25 & 20 & 20 & 5 & 150 & 2.40 & 2.42 \\
\hline
\end{tabular}

Table 2. Analysis of variance (ANOVA) for the quadratic model.

\begin{tabular}{ccccccc}
\hline Source & Sum of Squares & Df & Mean Square & F-Value & $p$-Value & Remarks \\
\hline Model & 0.2785 & 9 & 0.0309 & 47.72 & $<0.0001$ & significant \\
Water-to-material Ratio (A) & 0.0128 & 1 & 0.0128 & 19.74 & 0.0012 & significant \\
Extraction time (B) & 0.0128 & 1 & 0.0128 & 19.74 & 0.0012 & significant \\
Microwave Power (C) & 0.0040 & 1 & 0.0040 & 6.19 & 0.0321 & not significant \\
AB & 0.0003 & 1 & 0.0003 & 0.4818 & 0.5034 & not significant \\
AC & 0.0003 & 1 & 0.0003 & 0.4818 & 0.5034 & not significant \\
BC & 0.0078 & 1 & 0.0078 & 12.05 & 0.0060 & significant \\
A & 0.0889 & 1 & 0.0889 & 137.14 & $<0.0001$ & significant \\
B $^{2}$ & 0.0889 & 1 & 0.0889 & 137.14 & $<0.0001$ & significant \\
C $^{2}$ & 0.1101 & 1 & 0.1101 & 169.73 & $<0.0001$ & significant \\
Residual & 0.0065 & 10 & 0.0006 & - & - & not significant \\
Lack of Fit & 0.0032 & 5 & 0.0006 & 0.9456 & 0.5237 & - \\
Pure Error & 0.0033 & 5 & 0.0007 & - & - & - \\
Std. Dev. & 0.0255 & - & $R^{2}$ & 0.9772 & - & - \\
Mean & 2.25 & - & Adjusted $R^{2}$ & 0.9568 & - & -
\end{tabular}


The quadratic model is therefore could be written as follows:

$$
\mathrm{Y}=2.42+0.0306 \mathrm{~A}+0.0306 \mathrm{~B}+0.0171 \mathrm{C}-0.0063 \mathrm{AB}+0.0062 \mathrm{AC}+0.0312 \mathrm{BC}-0.0786 \mathrm{~A}^{2}-0.0786 \mathrm{~B}^{2}-0.0874 \mathrm{C}^{2}
$$

Overall, the model suitability was determined through several indicators, including the model F-value, $p$-values of variables, F-value of lack of fit, and $\mathrm{R}^{2}$. To be specific, the model is less likely to feature noise due to the significant model F-value of 47.72. Regarding variable $p$-values, model results showed that most variables, except for $\mathrm{AC}$ and $\mathrm{AB}$, are statistically significant. This suggests that model reduction is unnecessary and that the resulting model is adequate to explain the data. In addition, the high $R^{2}$ and the closeness of data points corresponding to actual and predicted data to the 45-degree line (Figure 10) suggested the relative accuracy of the quadratic model.

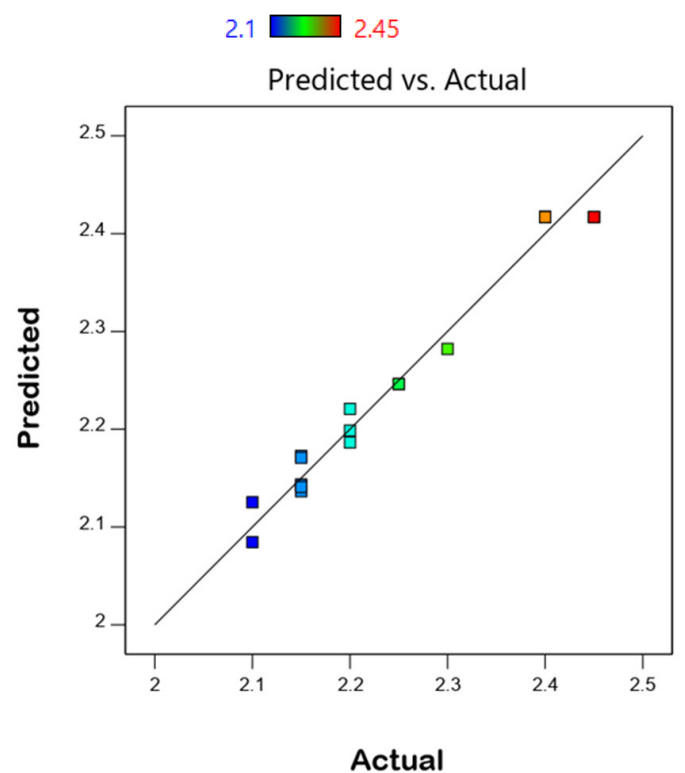

(a)

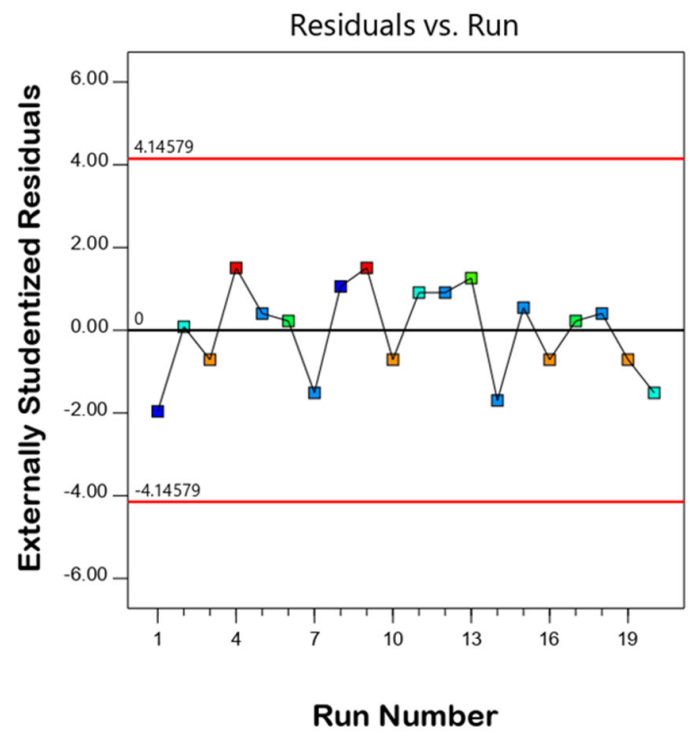

(b)

Figure 10. Plots of (a) actual data versus predicted data and (b) residuals calculated from the model.

Plotting the response variable (oil yield) with respect to two variables yielded three surfaces as follows.

Closer examination of the surface plots in Figure 11 revealed the hill-shaped relationship between the experimental factors and the response. Evidently, the plot indicated the presence of a maximum oil yield where the oil yield declines thereafter with pairwise increases of two conditions. Attempting to determine the maxima of the model yielded optimum conditions of $A=1 / 21, B=5.2$, and $C=151$, corresponding to the predicted yield of $2.42 \%$. To validate these parameters, we conducted three real experiments with similar parameters. The results were shown in Table 3. Reportedly, the actual yields in experiments conducted with optimal conditions were found to be approximate to the predicted yields. This suggests the suitability of the quadratic model for predicting the yield.

Table 3. Extraction yields at optimum conditions.

\begin{tabular}{cccccccc}
\hline Mesh Size & $\begin{array}{c}\text { Preservation } \\
\text { Method }\end{array}$ & $\begin{array}{c}\text { NaCl } \\
\text { Concentration } \\
\mathbf{( \% )}\end{array}$ & $\begin{array}{c}\text { Soak } \\
\text { Time (h) }\end{array}$ & $\begin{array}{c}\text { Ratio } \\
\mathbf{( g / m L})\end{array}$ & $\begin{array}{c}\text { Temperature } \\
\text { Extraction }\left({ }^{\circ} \mathbf{C}\right)\end{array}$ & $\begin{array}{c}\text { Time } \\
\text { Extraction (h) }\end{array}$ & $\begin{array}{c}\text { Yield (\%) } \\
\text { (\%) }\end{array}$ \\
\hline 160 & $10^{\circ} \mathrm{C}$, lidded & 2 & 3 & $1 / 21$ & 151 & 5.2 & $2.42(\mathrm{predicted})$ \\
160 & $10^{\circ} \mathrm{C}$, lidded & 2 & 3 & $1 / 21$ & 150 & 5.2 & $2.45(\mathrm{actual})$ \\
160 & $10^{\circ} \mathrm{C}$, lidded & 2 & 3 & $1 / 21$ & 150 & 5.2 & $2.45(\mathrm{actual})$ \\
160 & $10^{\circ} \mathrm{C}$, lidded & 2 & 3 & $1 / 21$ & 150 & 5.2 & $2.45(\mathrm{actual})$ \\
\hline
\end{tabular}




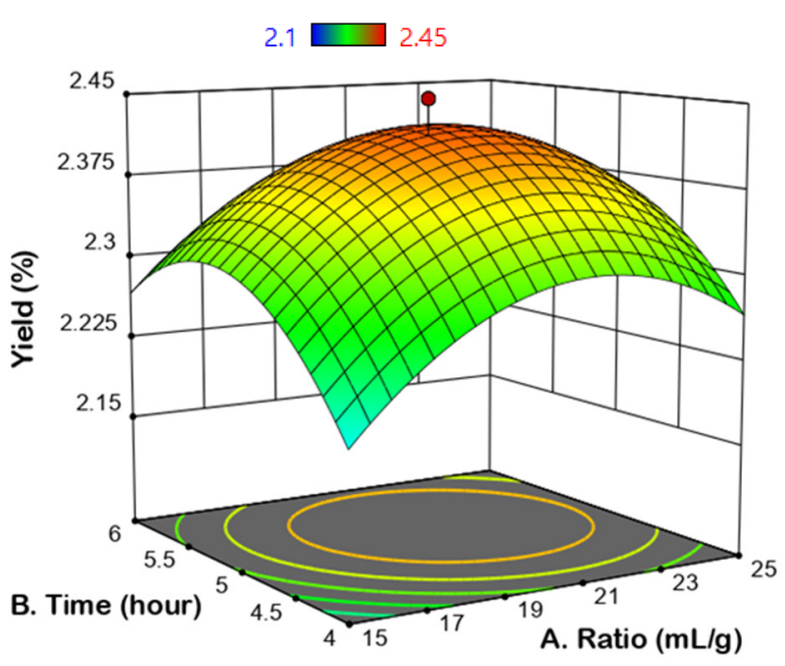

(a)

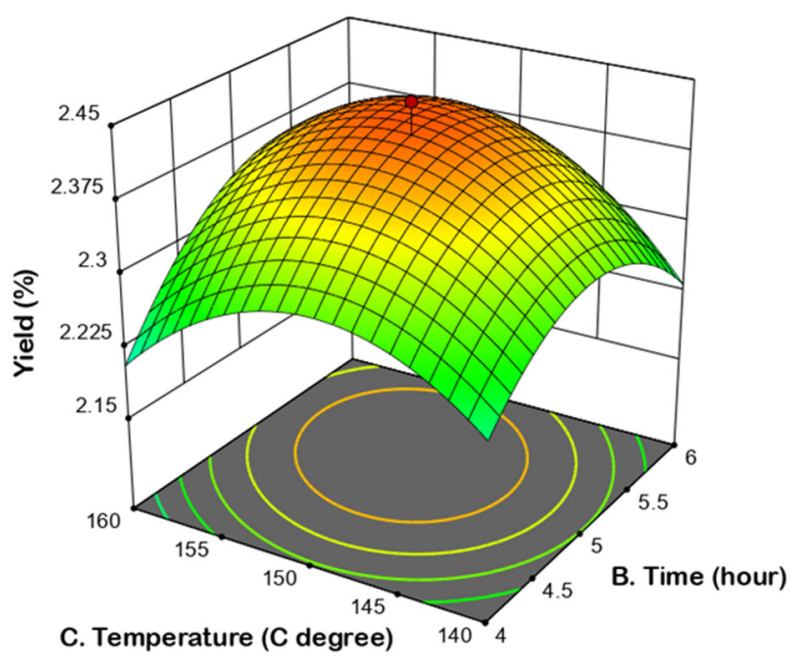

(b)

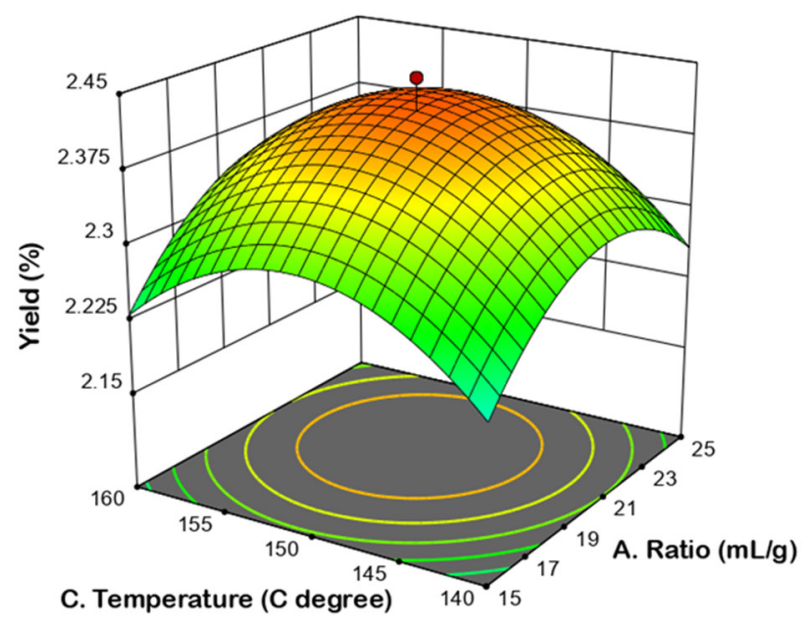

(c)

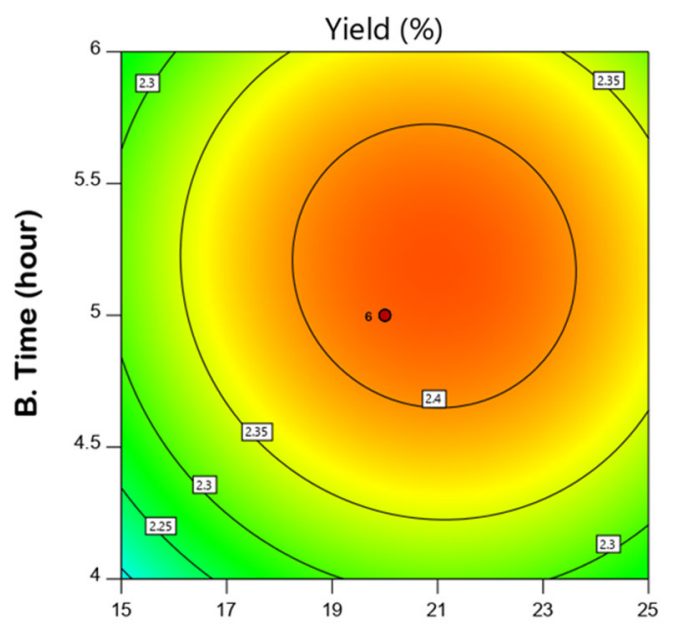

A. Ratio (mL/g)

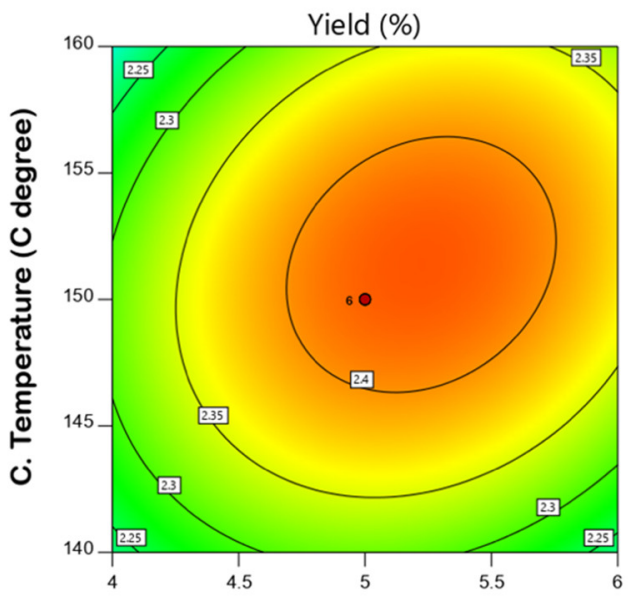

B. Time (hour)

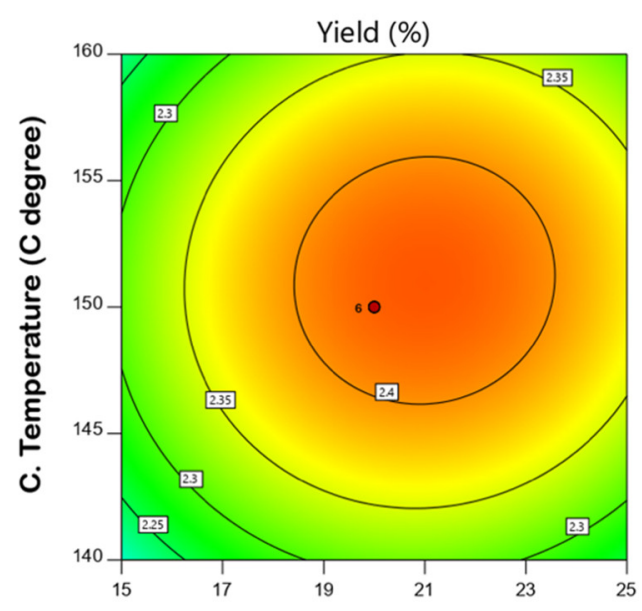

A. Ratio $(\mathrm{mL} / \mathrm{g})$

Figure 11. Surface and contour plots with respect to (a) time and ratio, (b) temperature and time, and (c) ratio and temperature. 
In comparison with previous studies, some main points regarding the conditions of extraction of the oil are summarized as follows (Table 4).

Table 4. Comparison of black pepper oil yields from different studies.

\begin{tabular}{|c|c|c|c|c|c|}
\hline & Current Study & [32] & [33] & [34] & [35] \\
\hline Extraction yield & $2.45 \%$ & $1.5 \%$ & $2.8 \%$ & $2.2 \%$ & $2.6 \%$ \\
\hline Extraction method & Hydro-distillation & $\begin{array}{l}\text { Supercritical Fluid } \\
\text { Extraction }\end{array}$ & Steam Distillation & Hydro-distillation & Superheated Steam \\
\hline Material & Vietnamese black pepper & Greek black pepper & Indian pepper & Indian pepper & French black pepper \\
\hline
\end{tabular}

\subsection{The Result of GC-MS}

The results of the GC-MS analysis of the black pepper essential oil extracted at the optimized conditions were presented in Table 5. We have identified 26 compounds representing $99.86 \%$ of the total compounds in the black pepper essential oils. Amounts of other non-identified compounds present in the oils were negligible. Compounds were considered as traces when their amounts were less than $0.05 \%$. In our study, we found that 3 -carene $(29.21 \%)$, D-limonene $(20.94 \%), \beta$-caryophyllene $(15.05 \%), \alpha$ - pinene $(4.69 \%)$, and $\beta$-pinene $(9.77 \%)$ are major constituents of black pepper essential oil (Figure 12). In comparison with the results of previous studies, the contents of 3-carene and D-limonene were significantly higher than most results of other black pepper cultivars. For $\beta$-caryophyllene, the compound was found in lower quantity in comparison with black pepper from India when extracted with the same conditions. It is also worth noting that unlike other black pepper cultivars, Vietnamese black pepper oil lacks a sabinene component.

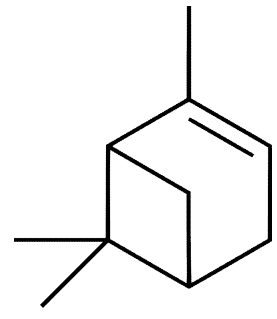

alpha-pinene

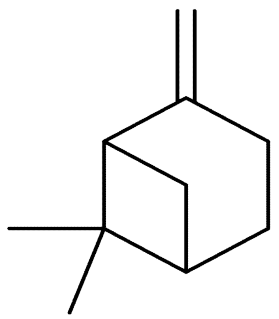

beta-pinene

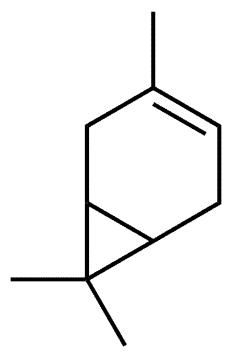

3-carene

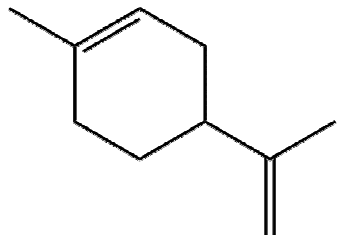

D-limonene

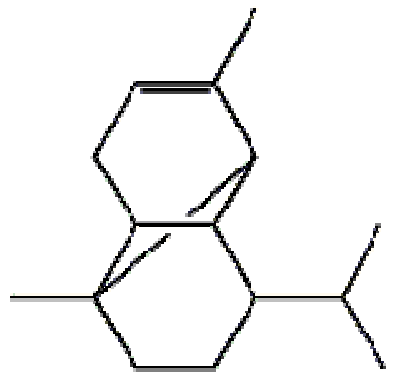

alpha-copaene

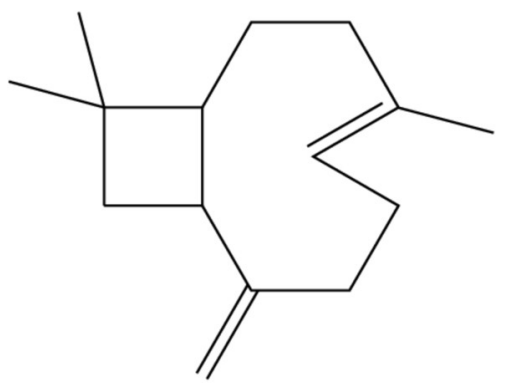

beta-caryophyllene

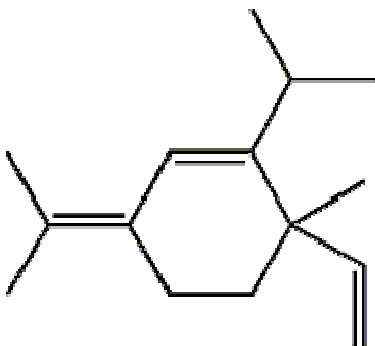

alpha-elemene

Figure 12. Major components of black pepper essential oil. 
Table 5. A comparison with regard to the method of extraction.

\begin{tabular}{|c|c|c|c|c|c|c|c|c|c|}
\hline $\begin{array}{l}\text { R.T. } \\
(\min )\end{array}$ & Compounds & $\begin{array}{l}\text { This } \\
\text { Study }\end{array}$ & $\begin{array}{c}\text { Greek } \\
\text { BP } \\
\text { SF } \\
{[32]}\end{array}$ & $\begin{array}{c}\text { Greek } \\
\text { BP } \\
\text { HD } \\
{[32]}\end{array}$ & $\begin{array}{c}\text { France } \\
\text { BP } \\
\text { SH } 175^{\circ} \mathrm{C} \\
{[35]}\end{array}$ & $\begin{array}{c}\text { Pharmacopoeia } \\
{[35]}\end{array}$ & $\begin{array}{c}\text { Indian } \\
\text { BP } \\
\text { HD } \\
{[34]}\end{array}$ & $\begin{array}{c}\text { Indian } \\
\text { BP } \\
\text { SD } \\
{[33]}\end{array}$ & $\begin{array}{c}\text { Indian } \\
\text { BP } \\
\text { NR } \\
{[36]}\end{array}$ \\
\hline 5.19 & $\alpha$-pinene & 4.69 & 0.43 & 2.15 & - & 2.48 & 4.75 & 8.2 & $2.0-14.6$ \\
\hline 6.71 & $\beta$-pinene & 9.77 & 3.47 & 4.21 & 8.32 & 8.23 & 6.71 & 12.0 & $4.8-23.9$ \\
\hline 7.13 & $\beta$-myrcene & 2.91 & - & - & - & - & 0.89 & 1.2 & $0-11.1$ \\
\hline 8.12 & 3-carene & 29.21 & 4.91 & 4.34 & 4.63 & 4.82 & 0.43 & 16.0 & $0-7.9$ \\
\hline 9.2 & o-cymene & 0.86 & - & - & 0.65 & 0.92 & - & 0.3 & $0.1-1.3$ \\
\hline 9.23 & D-limonene & 20.94 & 6.81 & 6.32 & 19.74 & 19.30 & 16.88 & 19.0 & $9.5-22.5$ \\
\hline 10.77 & $\alpha$-phellandrene & 0.09 & - & - & - & - & 2.14 & 1.3 & $0.1-7.4$ \\
\hline 11.06 & $\delta$-terpinene & 0.20 & - & - & - & - & 0.52 & 0.1 & $0.1-0.3$ \\
\hline 12.99 & terpinolene & 0.04 & - & - & - & - & 0.21 & 0.2 & $0-0.3$ \\
\hline 13.35 & $\alpha$-terpinene & 1.10 & - & - & - & - & - & 0.1 & $0.1-0.3$ \\
\hline 14.86 & linalool & 0.42 & 1.28 & 0.59 & $\operatorname{tr}$ & 0.62 & 0.27 & 0.8 & $0.1-0.6$ \\
\hline 18.32 & $\alpha$-phellandren-8-ol & 0.05 & - & - & - & - & - & & - \\
\hline 19.42 & $\alpha$-terpineol & 0.11 & - & - & $\operatorname{tr}$ & 0.08 & 0.19 & 0.8 & $0-0.3$ \\
\hline 22.64 & $\alpha$-elemene & 3.49 & 0.23 & 0.3 & 3.95 & 3.91 & - & $\operatorname{tr}$ & - \\
\hline 22.84 & $\alpha$-cubebene & 0.19 & 0.52 & 0.38 & - & 0.09 & 0.26 & $\operatorname{tr}$ & $0.1-0.7$ \\
\hline 23.33 & copaene & 3.19 & 6.83 & 5.42 & 1.36 & 1.33 & 6.30 & 0.2 & $0.1-1.7$ \\
\hline 23.52 & aromadendrene & 1.09 & - & - & - & - & - & - & - \\
\hline 24.08 & $\beta$-caryophyllene & 15.05 & 12.43 & 8.91 & 41.54 & 40.82 & 24.24 & 10.0 & $6.4-52.9$ \\
\hline 24.60 & humulene & 2.10 & 3.31 & 2.36 & 1.97 & 1.72 & 1.38 & 0.3 & $0-1.4$ \\
\hline 24.94 & germacrene-D & 0.15 & - & - & - & - & 0.40 & - & - \\
\hline 25.08 & eudesma-4(14)-11-diene & 0.56 & - & - & - & - & - & - & - \\
\hline 25.17 & $\alpha$-selinene & 0.5 & 3.68 & 2.64 & $\operatorname{tr}$ & 1.25 & 0.46 & $\operatorname{tr}$ & $0-0.8$ \\
\hline 25.28 & $\beta$-bisabolene & 0.01 & - & - & - & - & 7.69 & 0.6 & - \\
\hline 25.44 & $\beta$-cadinene & 1.24 & 3.73 & 2.14 & 0.09 & 0.17 & - & $\operatorname{tr}$ & - \\
\hline 26.33 & caryophylene oxide & 0.89 & 7.94 & 12.48 & 0.58 & 0.69 & 0.47 & 0.7 & $0.5-4.5$ \\
\hline 26.85 & isopathuleol & 1.01 & - & - & - & - & - & - & - \\
\hline- & sabinene & - & 5.46 & 4.81 & 4.21 & 3.56 & 13.01 & 19.0 & $0-27.5$ \\
\hline
\end{tabular}

HD: hydrodistillation; SD: steam distillation; SF: supercritical fluid extraction; SH: Superheated steam; NR: method not reported; -: not detected; tr: trace. 
The sheer abundance of 3-carene and D-limonene suggested that Vietnamese black pepper is a promising ingredient for the production of insect repellent [37] and air deodorizer. To elaborate, when making a comparison of the compositions of different essential oils, it is revealed that D-limonene and camphor exhibit mosquito repellency [38]. Also, in another study, the combination of 3-carene, D-limonene, and $\alpha$-pinene was shown to be prevalent in air fresheners and air deodorizers [39]. Other possible uses of the essential oil of the Vietnamese black pepper could include antioxidant, antimicrobial, or insecticidal agent applications [40-42].

\section{Conclusions}

In this study, the conditions for optimal hydrodistillation extraction of essential oil from Vietnamese black pepper (Piper nigrum L.) seeds were investigated. In addition, GC-MS also was used to reveal the chemical composition of the produced oil. Optimal conditions included a water-to-material ratio of $1: 21 \mathrm{~g} / \mathrm{mL}$, the extraction temperature of $150^{\circ} \mathrm{C}$, and the extraction time of $5.2 \mathrm{~h}$. In addition, the materials should be preserved at a temperature of $10{ }^{\circ} \mathrm{C}$ in lidded storage. These conditions corresponded to the optimum efficiency of $2.45 \%$. Furthermore, twenty-six compounds of essential oil in black pepper have been identified using gas chromatography-mass spectrometry (GC-MS). The results showed that 3-carene (29.21\%), D-limonene (20.94\%), $\beta$-caryophyllene (15.05\%), $\beta$-pinene $(9.77 \%)$, and $\alpha$-pinene (4.69\%) are the major constituents of the essential oil. From the analysis of the results obtained, it is possible to conclude that the essential oil extracted from Vietnamese black pepper is suitable for the production of insect repellant and air freshener.

Author Contributions: Investigation-T.H.T., L.K.H., T.P.D., D.H.N. and D.V.N.B.; Supervision-L.T.H.N., T.D.N., and L.G.B.; Writing—original draft, T.H.T.; Writing—review \& editing, D.C.N. \& Q.T.T.

Funding: This research was funded by Nguyen Tat Thanh University, Ho Chi Minh City, Vietnam.

Acknowledgments: The authors acknowledge Nguyen Tat Thanh University for providing facilities and chemicals during the research period.

Conflicts of Interest: The authors declare no conflict of interest.

\section{References}

1. Zhai, H.; Liu, H.; Wang, S.; Wu, J.; Anna-Maria, K. Potential of essential oils for poultry and pigs. Anim. Nutr. 2018, 4, 179-186. [CrossRef] [PubMed]

2. Suzan, A.K.; Selva, R. Recent progress in photochemical reaction on main components of some essential oils. J. Saudi Chem. Soc. 2018, 22, 855-875.

3. Hien, T.T.; Hao, H.H.N.; Chinh, N.D.; Nguyen, T.Q.; Tan, H.N.; Nhan, L.T.H.; Hai, D.N.; Tran, L.D.; Sy, T.D.; Trinh, D.N. Microwave-Assisted Extraction: Application to the Optimization of Essential Oil Extraction from Vietnamese Basil (Ocimum Basilicum) Using Response Surface Methodology. Processes 2018, 6, 206. [CrossRef]

4. Nicholas, S.; Graham, J. A Contemporary Introduction to Essential Oils: Chemistry, Bioactivity and Prospects for Australian Agriculture. Agriculture 2015, 5, 48-102.

5. Timothy, L.C.; Graham, L.J.; Nicholas, J.S. Volatiles from the Rare Australian Desert Plant Prostanthera centralis B.J.Conn (Lamiaceae): Chemical Composition and Antimicrobial Activity. Agriculture 2014, 4, 308-316.

6. Juliany, R.C.; Philip, G.C.; Corliss, A.O.; Steven, C.R. Essential oils as antimicrobials in food systems-A review. Food Control 2015, 54, 111-119.

7. Tien, T.K.D.; Francis, H.M.; Sylvain, A.; Xavier, F. Authenticity of essential oils. TrAC Trends Anal. Chem. 2015, 66, 146-157.

8. Luz María, C.I. Native Mexican aromatic flora and essential oils: Current research status, gaps in knowledge and agro-industrial potential. Ind. Crop. Prod. 2018, 111, 807-822.

9. Fan, Z.; Reuben, M.; Guantian, L. Physicochemical properties of black pepper (Piper nigrum) starch. Carbohydr. Polym. 2018, 181, 986-993. 
10. Fan, Z.; Reuben, M.; Guantian, L. Structure of black pepper (Piper nigrum) starch. Food Hydrocoll. 2017, 71, 102-107.

11. Bhupendra, M.G.; Goswami, T.K. Modeling of granular heat transfer in cryogenic grinding system: Black pepper seeds. Chem. Eng. Res. Des. 2019, 141, 302-316.

12. Swathy, J.S.; Prabhakar, M.; John, T.; Amitava, M.; Natarajan, C. Antimicrobial potency of high-energy emulsified black pepper oil nanoemulsion against aquaculture pathogen. Aquaculture 2018, 491, 210-220.

13. Olusegun, A.O.; Nour, H.A.; Rosli, B.M.Y.; Oluwaseun, R.A.; Nassereldeen, A.K. Chemical fingerprinting of biologically active compounds and morphological transformation during microwave reflux extraction of black pepper. Chem. Data Collect. 2018, 17-18, 339-344.

14. Anith, K.N.; Aswini, S.; Shilpa, V.; Radhakrishnan, N.V.; Deepa, S.N. Root colonization by the endophytic fungus Piriformospora indica improves growth, yield and piperine content in black pepper (Piper nigurm L.). Biocatal. Agric. Biotechnol. 2018, 14, 215-220. [CrossRef]

15. Maliha, S.; Tanweer, K.; Junaid, A.K.; Bilal, A. Effect of aqueous extract of black pepper and ajwa seed on liver enzymes in alloxan-induced diabetic Wister albino rats. Saudi Pharm. J. 2017, 25, 449-452.

16. Umadevi, P.; Anandaraj, M. Genotype specific host resistance for Phytophthora in black pepper (Piper nigrum L.). Physiol. Mol. Plant Pathol. 2017, 100, 237-241. [CrossRef]

17. Mousumi, M.D.; Haridas, M.; Sabu, A. Biological control of black pepper and ginger pathogens, Fusarium oxysporum, Rhizoctonia solani and Phytophthora capsici, using Trichoderma spp. Biocatal. Agric. Biotechnol. 2019, 17, 177-183. [CrossRef]

18. Christiane, P.O.A.; Dielly, C.F.L.; Rosivaldo, S.B. Influence of piperidine ring on stability and reactivity of piperine. Chem. Data Collect. 2018, 17-18, 138-142.

19. Meghwal, M.; Goswami, T.K. Piper nigrum and Piperine: An Update. Phytother. Res. 2013, 27, 1121-1130. [CrossRef]

20. Anette, T.; Carin, B.; Tina, W.; Stéphane, E.; Ankie, S.; Markus, F.; Paul, B. Black pepper constituent piperine: Genotoxicity studies in vitro and in vivo. Food Chem. Toxicol. 2014, 66, 350-357.

21. Pawin, P.; Preedajit, W.; Saowanee, K.; Varanuj, C.; Chatchai, M. Inhibition of intestinal chloride secretion by piperine as a cellular basis for the anti-secretory effect of black peppers. Pharmacol. Res. 2015, 100, 271-280.

22. Sayantani, D.; Paramita, B. Modeling of supercritical carbon dioxide extraction of piperine from Malabar black pepper. Mater. Today Proc. 2016, 3, 3238-3252.

23. Hien, T.T.; Nhan, N.P.T.; Trinh, D.N.; Van Ho, T.T.H.; Giang, L.B. Optimizing the Pomelo Oils Extraction Process by Microwave-Assisted Hydro-Distillation Using Soft Computing Approaches. Solid State Phenom. 2018, 279, 217-221. [CrossRef]

24. Bagheri, H.; Abdul Manap, M.Y.B.; Solati, Z. Antioxidant activity of Piper nigrum L. essential oil extracted by supercritical $\mathrm{CO}_{2}$ extraction and hydro-distillation. Talanta 2014, 121, 220-228. [CrossRef] [PubMed]

25. Sayantani, D.; Paramita, B. Nanoliposomal encapsulates of piperine-rich black pepper extract obtained by enzyme-assisted supercritical carbon dioxide extraction. J. Food Eng. 2017, 201, 49-56.

26. Kátia, S.A.; Denis, P.; Sandra, R.S.F. Sustainable extraction and encapsulation of pink pepper oil. J. Food Eng. 2017, 204, 38-45.

27. Moncef, C.; Leila, R.; Salem, H.; Giovanna, F. Chemical characteristics and compositions of red pepper seed oils extracted by different methods. Ind. Crop. Prod. 2019, 128, 363-370.

28. Henry, Y.S.; Andrew, B.; Archana, G.; Charles, L.C.; Tess, A.; Augustine, E.O.; Valtcho, D.Z.; Vicki, S. Hydrodistillation time affects dill seed essential oil yield, composition, and bioactivity. Ind. Crop. Prod. 2015, 63, 190-196.

29. Hao, C.; Hong, W.P.; Peng, H.W.; Xiu, D.Y.; Wan, C.Z.; Yao, D.; Hong, L.Z. Essential oils from Carex meyeriana Kunth: Optimization of hydrodistillation extraction by response surface methodology and evaluation of its antioxidant and antimicrobial activities. Ind. Crop. Prod. 2018, 124, 669-676.

30. Sarah, R.; Samir, A.; Salah, H. Kinetic Study and Optimization of Extraction Process Conditions. Energy Procedia 2017, 139, 98-104.

31. Henryk, H.J.; Anna, G. Analysis of black pepper volatiles by solid phase microextraction-gas chromatography: A comparison of terpenes profiles with hydrodistillation. J. Chromatogr. A 2015, 1418, 200-209.

32. Perakis, C.; Louli, V.; Magoulas, K. Supercritical fluid extraction of black pepper oil. J. Food Eng. 2005, 71, 386-393. [CrossRef] 
33. Pino, J.; Rodriguez-Feo, G.; Borges, P.; Rosado, A. Chemical and sensory properties of black pepper oil (Piper nigrum L.). Mol. Nutr. Food Res. 1990, 34, 555-560. [CrossRef]

34. Singh, G.; Marimuthu, P.; Catalan, C.; de Lampasona, M. Chemical, antioxidant and antifungal activities of volatile oil of black pepper and its acetone extract. J. Sci. Food Agric. 2004, 84, 1878-1884. [CrossRef]

35. Rouatbi, M.; Duquenoy, A.; Giampaoli, P. Extraction of the essential oil of thyme and black pepper by superheated steam. J. Food Eng 2007, 78, 708-714. [CrossRef]

36. Menon, A.N.; Padmakumari, K.P.; Jayalekshmy, A.J. Essential Oil Composition of Four Major Cultivars of Black Pepper (Piper nigrum L.). J. Essent. Oil Res. 2002, 14, 84-86. [CrossRef]

37. Dotolo, V. Pesticides Containing D-Limonene. U.S. Patent No. 4,379,168, 14 March 1983.

38. Gillij, Y.G.; Gleiser, R.M.; Zygadlo, J.A. Mosquito repellent activity of essential oils of aromatic plants growing in Argentina. Bioresour. Technol. 2008, 99, 2507-2515. [CrossRef] [PubMed]

39. Król, S.; Namieśnik, J.; Zabiegała, B. $\alpha$-Pinene, 3-carene and d-limonene in indoor air of Polish apartments: The impact on air quality and human exposure. Sci. Total Environ. 2014, 468-469, 985-995. [CrossRef]

40. Ibrahim, M.A.; Kainulainen, P.; Aflatuni, A. Insecticidal, repellent, antimicrobial activity and phytotoxicity of essential oils: With special reference to limonene and its suitability for control of insect pests. Agric. Food Sci. 2008, 10, 243-259. [CrossRef]

41. Mercier, B.; Prost, J.; Prost, M. The essential oil of turpentine and its major volatile fraction ( $\alpha$ - and $\beta$-pinenes): A review. Int. J. Occup. Med. Environ. Health 2009, 22, 331-342. [CrossRef]

42. Rothenberg, G.; Yatziv, Y.; Sasson, Y. Comparative autoxidation of 3-Carene and $\alpha$-Pinene: Factors governing regioselective hydrogen abstraction reactions. Tetrahedron 1998, 54, 593-598. [CrossRef]

(C) 2019 by the authors. Licensee MDPI, Basel, Switzerland. This article is an open access article distributed under the terms and conditions of the Creative Commons Attribution (CC BY) license (http:// creativecommons.org/licenses/by/4.0/). 